\title{
Investigating the Impact of Communication Satisfaction on Organizational Commitment: A Practical Approach to Increase Employees' Loyalty
}

\author{
Ghalia Ammari ${ }^{1}$, Barween Al Kurdi ${ }^{2}$, Muhammad Alshurideh ${ }^{1}$, Bader Obeidat ${ }^{1}$, Al-Hareth Abu Hussien ${ }^{2}$ \& \\ Ala'aldin Alrowwad ${ }^{1}$ \\ ${ }^{1}$ School of Business, The University of Jordan, Amman, Jordan \\ ${ }^{2}$ Marketing Department, Faculty of Business, Amman Arab University, Amman, Jordan \\ Correspondence: Muhammad Turki Alshurideh, Marketing Department, School of Business, University of \\ Jordan, Amman, Jordan. E-mail: m.alshurideh@ju.edu.jo
}

Received: June 20, 2015 Accepted: February 27, 2017 Online Published: March 8, 2017

doi:10.5539/ijms.v9n2p113 URL: http://doi.org/10.5539/ijms.v9n2p113

\begin{abstract}
Recently, employees are seen as important assets of organizations in which the majority of them cannot deal with employees properly or even underestimate their importance. One of the essential issues is increasing employees' organizational commitment, which in turn minimizes customers' switching behaviour and the way organizations usually communicate appropriately their internal market strategy. In order to have a better vision about such issue, this study is planned to investigate the impact of communicational satisfaction on organizational commitment. A variety of communicational satisfaction dimensions are taken into analysis; such dimensions include: communication climate, relationship to superiors, organizational integration, media quality, horizontal and informal communication, organizational perspective, relationship with subordinates and the personal feedback. In addition, three factors of organizational commitment were taken into considerations that are affective commitment, continuance commitment and normative commitment. The study followes the qualitative approach in collecting data from employees of Yahoo- Maktoob office in Amman/Jordan. Eight sub-hypotheses are developed and tested accordingly to conclude with the fact that communicational satisfaction has a significant and direct impact on organizational commitment.
\end{abstract}

Keywords: communication satisfaction, employees' loyalty, Jordan, organizational commitment

\section{Introduction}

Nowadays, communication plays an important role in achieving the goals and the missions of different organizations, since effective communication between stakeholders during service encounters helps to solve various potential problems inherent in the exchange of information and knowledge (Moorman et al., 1993; Shannak et al., 2010; Masa'deh, 2012; Almajali et al., 2016). However, Rousseau (1998) observes that since careers, in recent years, are described by changability rather than stability especially within the high competitive environments in the surrounding organizations, employees are unlikely and strongly identified with their employers. From an organization's perspective, this trend is disturbing because weak organizational commitment may mean that employees' productivity is less than optimal (Meyer et al., 1989; Vratskikh et al., 2016). Then by effective management communicational methods, opportunity for learning and work schedule flexibility (Rousseau, 1998), organizations can enhance their position among competitors, depending on the strong commitment of employees.

Communication is a critical interpersonal process consisting of a repetitive cycle of initiating, maintaining and terminating informational exchange (Applbaum, 1973) through verbal and nonverbal methods occurring at the actual IT service encounter (Sundaram et al., 2000; Altamony et al., 2012). Choosing the right communicational medium, the quality of interaction and the trust formed between service providers and clients at the service encounter are critical criteria used in evaluating further commitment to the relationship (Mattila et al., 2002; Obeidat et al., 2012).

Advances in informational and communicational technology have led to dramatic changes in the structure of industry and business environments (Michael et al., 2002; Obeidat et al., 2016). In order to compete efficiently in 
the market, organizations need to take advantage of communicational technologies, in order to support the internal operations, satisfy the customers' needs by producing customized products and services depending on their preferences. This research is intended to examine the effect of good communication on organizational commitment, knowing that increasing the level of commitment can enhance the organizational position which in turn leads to higher revenues and lower costs as a result of increasing both employees and customers' loyalty and minimizing switching behavior.

\subsection{Research Problem and Importance}

The large development of informational technology gives Internet organizations many opportunities that support their products and improve the quality of their services, yet some of these organizations either cannot achieve high revenues or cannot use their technologies efficiently within their internal activities. This may be due to some reasons like: the nature of different communicational channels and methods by which the top management can reach its employees within the organization, the rapid development of technologies, the lack of understanding which informational technologies are necessary and suitable for the organization, and the changing and demanding environment surrounding the organization. Accordingly, organizations have started to think deeply about creating methods and ways that can help to them reach their employees on both the organizational and personal levels around the globe regardless their physical location or their cultural availablility in different countries. If they employ global strategies in multinational organizations to recognize their brands, and to deliver the customers' needs and wants, they will improve their revenues.

This research aims at answering two main questions: First, What is the relationship between communicational satisfaction and organizational commitment? Second, how can communicational channels improve the commitment and loyalty of employees in internet organizations? Based on the previous questions, the study needs to investigate how communication affects employees who witnessed the differences in two organizations which are Maktoob and Yahoo! before and after the acquisition. Maktoob and Yahoo! organizational acquisition process took place in 2010 and this study tends to have a look at the implications of different al channels and methods and test their effect on the commitment of employees in addition to overall performance. Moreover, this research tries to provide different tools and methods which can be used by Internet firms to develop and enhance their communicational processes which in turn play an essentialrole inenhancing organizational commitment, and their subsequent implications on performance, gaining profits, and establishing a strong brand image among competitors.

Rousseau (1998) has suggested two ways through which organizations may strengthen employees' organizational commitment today. First, organizations can enhance employees' perceptions of organizational membership. Second, organizations can demonstrate to employees that they are cared for and valued by their employers. Significantly, these organizations in recent years have been struggling to find effective ways to enhance employees' organizational commitment (Mitchell et al., 2001). Thus, the importance of this study can be summarized as building strong evidence regarding the communicational channels which internally can influence organizational commitment, so internet firms can benefit from such techniques to add value in one way, and to enhance and improve the relationships between different parties within the whole organization. In addition, the review of literature explores how previous studies did not focus on the relationship between the two variables which are: communication and commitment. Keeping in mind that this research provides recommendations and suggestions that can be used in future studies to create a distinctive competitive advantage based on the internal capabilities and competences and to gain bigger market share and to expand in new markets. To sum up, the goal of this research is to determine the effect of communicational satisfaction on organizational commitment and to provide a deep understanding of the communicational management process depending on the team structure used in multinational organizations.

\section{Literature Review}

This part provides a deep theoretical analysis of the fields of communication satisfaction and organizational commitment.

\subsection{Communicational Satisfaction}

Organizations and institutional communication professions have been continually exploring effective measurement metrics for their communication initiatives, focusing on how communication practices can be effectively linked to improved financial performance at the organizational level (Broom \& Dozier, 1983; Menget al., 2012; Masa'deh et al., 2015). On the other hand, a research by Yammarino et al. (1988) who studied the relationship between the communication among the employees of the organization and work importance, like the effort spent by them, and the level of job satisfaction. Garnett \& Kouzmin (1997, cited Lorch, 1978) stated that 
"perhaps nothing is more important to successful administration than successful communication" (p. 16). The organizational context in which organizations communicate is scarcely considered as is illustrated by Pandey \& Garnett (2006). Keeping in mind that organizations deal with external environment, the continuous changes made to information and communication societies and the increasing globalization of the economy result in a growing complexity in economic and social systems. Consequently, this may lead to incomplete information and uncertainty regarding possible courses of action, which then require increasingly trustworthy action on the part of individuals, institutions and organizations. From that corner, the importance of communication appears.

Communication is related to technological methods used; like sophistication of the communication technologies, ease of use, number of communication options, etc. Examples of technology types used in communication include e-mail, voice mail, audio/video conferencing, and web-based ordering. In the internet organizations, the online communication generally refers to the computer-mediated exchange of messages between sender and receiver; whether it is between managers and employees, or between employees themselves, and the term is used synonymously with the term computer-mediated communication.

Communication is an essential concept in organization and management theory (Thompkins, 1987) and emerged from scholars of organizational communication (Goldhaber, 1993; Jablin et al., 1987). Within the same context, communication audits consistently show that communication climate, communication with supervisors (Madlock, 2010), and personal feedback are the dimensions, most strongly, correlated with overall communication satisfaction (Alshurideh, 2014; Pincus, 1986). Many scholars such as Holland et al. (1999), Alshurideh \& Al-dmour (2008), Al-Duhaish et al. (2014) suggested that employing communication tools such as reference groups, newsletters, monthly bulletins or weekly meetings are used to keep users informed about the implementation of many project progresses. Thus, the role of communication is an important factor in understanding the value of intangible organizational assets (Ritter, 2003). Communication within organizations is linked with higher levels of performance and service (Tourish \& Hargie, 2009), generating communication capital (Malmelin, 2007), and social capital (Lee, 2009; Alshurideh et al., 2015), are grounded in organizational relationships. Hence, it is important for managers to be able to assess internal communication.

A study conducted by Postmes et al. (2001) indicated that organizational communication is regarded as a means of creating conditions for commitment, while other studies have shown the importance of communication for perceptions of jobs, work units, and supervisors. Recently minimal attention has been given to what employees would like their organizations to communicate. As Chen et al. (2006, p. 242) mentioned, "a review of the research on organizational processes concluded that member satisfaction with organizational communication practices has been ignored". But Goldhaber et al. (1978) found that an employee's primary needs include more information about personal, job-related matters, information about organizational decision making, and a greater opportunity to voice complaints and evaluate superiors. According to the consultancy, Watson (2010), "most firms do well at communicating about the business; however, less than half of firms report they are effective at communicating to employees regarding how their actions affect the customer or increase productivity"(p. 9). In order to satisfy the users, organizations should involve keeping customers happy both in day-to-day interactions and in more global and long-term perspective (Hunt, 1977; Johnson \& Fornell, 1991).

\subsection{Organizational Commitment}

Organizational commitment has been extensively studied in Western management research and remains of substantial importance to managers, given the meta-analytic evidence of its association with withdrawal behaviors such as absenteeism, intentions to quit, and turnover, as well as higher levels of organizational citizenship behaviour (Mathieu \& Zajac, 1990; Meyer et al., 2002). Organizational satisfaction and commitment have been identified as a precedent to the construction of job's satisfaction (Alshurideh et al., 2010; Alshurideh et al., 2012; Alshurideh et al., 2014; Al-dweeri et al.,2017), organizational citizenship behavior (Alshurideh et al., 2015), organizational performance (Alkalha et al., 2012), perceived organizational and management support (Shannak et al., 2012; Zu'bi et al., 2012), organizational justice (Laschinger, 2004), productivity (Mathieu \& Zajac, 1990), service quality (ELSamen \& Alshurideh, 2012), and job performance (Masa'deh et al., 2016).

Commitment depends upon the nature of job and the organizational context. If employees have high commitment levels, they will work harder, and perform better than those with lower levels of commitment. On the other hand, if employees have low levels of commitment, they may leave the organization and cause high turnover. In terms of encouraging hard work, the practices of management within organization can highly affect the level of commitment among employees. The changes in the workforce have a significant effect on commitment; for example the downsizing strategies, and hiring employees with different values to the organization, all these practices may lead to lower commitment levels (D'Amat et al., 2008). When there are 
many advantages associated with high commitment levels of employees, both Kwantes (2007) and Alshurideh et al. (2012) pointed out that organizational commitment can increase: human capital, social capital, the retention of knowledge in organizations and transfer of knowledge and experience in organizations' units.

The individual level linkages between organizational commitment and turnover and between organizational commitment and performance are strongly supported in analysis (Cooper-Hakim \& Viswesvaran, 2005; Riketta, 2002). Al Kahtani (2013 cited Michaels et al., 2001) discussed the importance of organization commitment that is usually shaped by business leaders whose responsibilities are mainly concerned with attracting, motivating and retaining employees especially those who are seen as key talents in retaining customers (Alshurideh, 2016, 2016, 2016) and efficient in applying ethical business and marketing practices (Alshurideh et al., 2016).

In order to build high organizational commitment among employees, the top management of organizations must build strategies and work have practices to reinforce one another in order to produce such settings (Hom et al., 2009). Individuals with higher levels of organizational commitment have a sense of belonging and identification with the organization that increases their desire to pursue the organization's goals and activities, and their willingness to remain a part of the organization (Meyer \& Allen, 1991; Mowday et al., 1982). Furthermore, organizational commitment continues to be valued by organizational leaders (Morrow, 2011) despite the fact that organizations are currently operating in a historical era no longer characterized by long term employment (e.g., Cappelli, 2000). In addition, downsizing and the emergence of a new generation of employees have been identified as possible explanations for lower commitment levels (D'Amato \& Herzfeldt, 2008). Literature revew has demonstrated that employees' commitment to the organization has a variety of important organizational consequences. Several studies report negative correlations between organizational commitment and both employee intention to leave the organization and actual turnover. Additionally, literature revew indicates that employees with strong affective commitment to the organization work harder at their jobs and perform better than those with lower levels of affective commitment.

Many researches focused on studying organizational commitment. As a case in point, a study by Akroyd et al. (2009) examines the predictive value of selected work rewards (task involvement, task significance, general working conditions, supervision and salary) on organizational commitment. It comes at a conclusion that all of the above variables had a significant and positive impact on organizational commitment, with salary accounting for the smallest change in the variance of commitment. Another study provides valuable information about how organizational commitment affects relevant outcomes, e.g., employees' turnover intentions, organizational citizenship behavior (OCB), and job satisfaction (Mathieu \& Zajac, 1990; Meyer et al., 2002; Alshurideh et al., 2015). Some studies give a hint about the link between organizational commitment and performance; however, several meta-analyses have shown that this link is rather weak (Cohen, 1991; Mathieu \& Zajac, 1990; Randall, 1990; Riketta, 2002). Additionally, some studies suggest that commitment develops even before an employee enters a company (O'Reilly \& Caldwell, 1981), or at a very early stage in a new job position (Porter et al., 1976). In the rationalization process, organizational commitment in turn causes positive attitudes toward the job (Bem, 1967; Salancik \& Pfeffer, 1978).

Giving the fact that organizational commitment is one of the main reasons for these employees to stay (Hausknecht et al., 2009). However, in large organizations or after mergers or acquisitions, employees' commitment to the organization as a whole may be questionable (Riketta \& Van Dick, 2005; Van Dick \& Riketta, 2006). As a result, organizational commitment has been conceptualized in terms of the strength of an employee's involvement in and identification with an organization (Mowday et al., 1982). Depending on the attitudinal approach, commitment is a positive feeling toward the organization which depends on what employees experience on the job and how they perceive the organization (Mowday et al., 1982).

The organizational commitment concept emerged from studies exploring employee-organization linkages. Previous research has viewed that organizational commitment continues to be a powerful attitudinal response in employees (Scott-Ladd et al., 2006). In fact, Rathi \& Rastogi's (2009) literature review on organizational commitment and found that it has potential to predict organizational outcomes such as an increase in job performance, reduced turn over and withdrawal cognitions, lower absenteeism rate, and increased organizational behaviour. In this research, the focus is on the study of Meyer \& Allen (1991) as they proposed the three-component model, which distinguishes affective, continuous, and normative commitment. An employee will remain with an organization because he/she wants to affective commitment, has to have continuous commitment, or feels compelled to do so (normative commitment).

\subsection{Communication Satisfaction and Organizational Commitment}

Communication is the extent to which organizations provide their employees with organization-related 
information, such as information about changes in organizational policies and procedures, financial results, employee and group successes, and customer feedback (Vandenberg et al., 1999). Construction of organizational commitment has been researched extensively. Some of these studies have demonstrated the relationships between commitment and several other organizational variables:, such as: (a) absenteeism (Steers, 1977; Larson \& Fukami, 1984); (b) leadership style (Morris \& Sherman, 1981); (c) job performance (Mowday et al., 1974; Steers, 1977); (d) turnover (Angel \& Perry, 1981); and (e) communication openness (Argyris in Housel \& Warren, 1977). In fact, there is a lack of research on the relationship between organizational communication and commitment and any relationship that may exist between these two variables is more implied than demonstrated (Putti et al., 1990). According to Downs et al. (1995), few studies have supported the relationship between communication satisfaction and organizational commitment.

Keyton (2005) defined organizational communication as "a complex and continuous process through which organizational members create, maintain, and change the organization" (p. 33). Based on this definition, communication has been linked to organizational commitment of continuous development in several ways. Allen (1992), for example, found that, especially in organizations involved in total quality management, communication variables explained up to 59 percent of the variance in organizational commitment. Ridder (2004) found task-related information to be important for organizational commitment, while McDonald \& Gandz (1991) suggested that commitment was especially important for the human relations within the organization.

Organization interrelated information can be bridged to the whole employees via a set of channels such as group meetings, group leaders, brochures and newsletters, managers, company websites, and organisation mission statements and objectives (Argenti, 1998; Soupata, 2005). Accordingly, these methods can affect organizational commitment, because employees feel they have a sense of ownership. In addition, knowing more about the internal procedures, will increase the employees' attachment to their employers because they will see themselves as core members, and contribute to the organization's goals. Some researchers have traditionally divided the organizational commitment interrelated concepts or components known as: the attitudinal and the behavioral commitment (McCarthy et al., 2013, p. 52 Cited Kuvass, 2003). Attitudinal commitment represents the strength of an individual's loyalty to the organization and emphasizes his/her identification and involvement with it. Behavioural commitment, on the other hand, reflects the process whereby individuals link themselves to an organization, because of the costs involved in leaving it. Keyton (2005) defines organizational communication as "a complex and continuous process through which organizational members create, maintain, and change the organization. Managers usually play an important role in this process, as they have to provide a bigger picture of the organization and the environment around it (Robson \& Tourish, 2005). The centrality of managers in the process suggests that there is a link between managerial communication and attitudes about the organization, so the subordinates can create attitudes from the messages they receive from the managers, and behave according to the information they have. Therefore, one of the consequences associated with such behaviour is, the commitment of employees to the organization.

Organizational communications, commitment, and job satisfaction are all variables that affect organizational performance, so poor organizational communication has been found to lower organizational commitment (Kramer, 1999; Rodwell et al., 1998). The effect of organizational communication on the levels of commitment between employees has attracted the attention of some researchers (Goris et al., 2000; Pettit et al., 1997; Stuart, 1999). As Stuart (1999) argued, communication construction can affect empowerment of employees, which in turn affects organizational commitment. Additionally, organizational commitment has three basic components: identification with the organization's goals and values; involvement in the organization through effort; and loyalty to the organization (Al-Meer, 1989), so it's important to link the effort of communicating the goals, values, policies, and the waybehined dealing with customers with superiors and subordinates across the organization, and the overall enhancement of the levels of commitment among employees. Although it is hard to manage employees' commitment (Gould-Williams, 2003), communicational methods play a significant role in enhancing commitment levels, through the Human Resource Management (HRM) practices, and to ensure the future vision and the strategy for the organization. Consequently, increasing the ownership practices by increasing the involvement of employees in the decision making process, and through the delegation of some tasks to them and accounting them responsible for the actions they make, will affect overall organizational commitment. On the other hand, communication satisfaction can be seen as a specialty and there is a need to determine the skills and knowledge that should be available inside the firm. The knowledge-skill attributes were identified in the first round of Delphi's study such as knowledge of multiple languages, writing and editing, basic psychology, organizing events, communicating and understanding different cultures, understanding of various media (online, video, print, etc.), understanding of research techniques, change management, project 
management, marketing, working with media, branding and design. Moreover, communication satisfaction and organizational commitment is a "psychological stabilizing or obliging force that binds individuals to courses of action relevant" to the organization (Bentein et al., 2005, p. 358).

To sum up, while a number of studies exist to investigate the relationship between communications satisfaction and organizational commitment, there is no evidence on the said relationship in Jordan. Thus, and with reference to the objectives of this study, the research tries to contribute to the existing literature by explaining the relationships among studied variables as shown in the study framework below.

\section{Theoretical Framework}

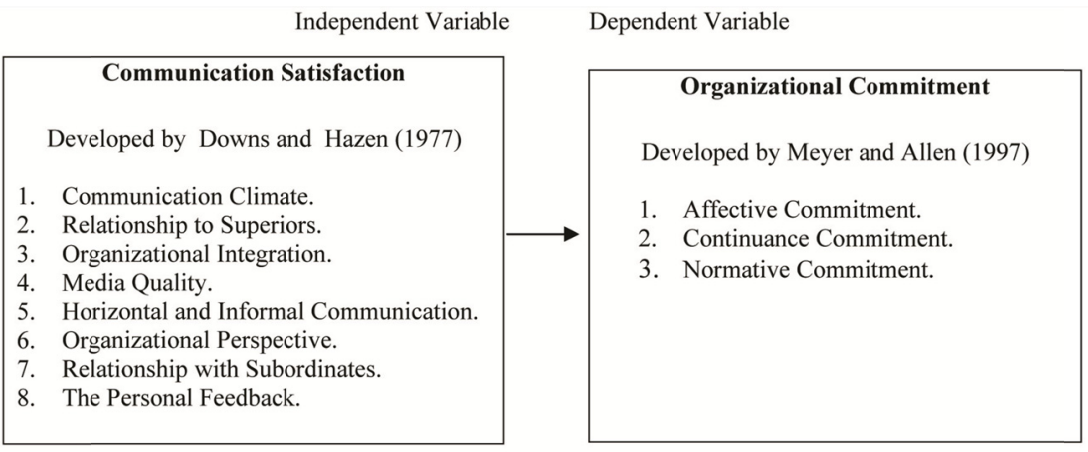

Figure 1. The theoretical framework

The model illustrated in the above figure is constructed according to the objectives of this study. The hypothesized linkage indicates that communication satisfaction is linked to organizational commitment. As discussed previously, the problem statement argues that communication satisfaction has an impact on organizational commitment, and improve the level of loyalty of employees in the organization. In addition, as explained in more details earlier, communication satisfaction has a positive impact on organizational commitment.

\section{Hypotheses}

Depending on the theoretical framework above the main hypothesis is as follows:

$\mathbf{H 1}_{\mathbf{0}}$ : There is no statistically significant relationship between communication satisfaction and organizational commitment.

To test the relationship between communication satisfaction and organizational commitment, the first main hypothesis is further divided into the following sub-hypotheses:

H1 $\mathbf{a}_{\mathbf{0}}$ : There is no statistically significant relationship between communication climate and organizational commitment.

$\mathbf{H 1}_{\mathbf{b} \mathbf{0}}$ : There is no statistically significant relationship between the relationship to superiors and organizational commitment.

$\mathbf{H 1} \mathbf{c}_{\mathbf{c} 0}$ : There is no statistically significant relationship between organizational integration and organizational commitment.

H1d0: There is no statistically significant relationship between media quality and organizational commitment.

H1e0: There is no statistically significant relationship between horizontal and informal communication and organizational commitment.

H1f0: There is no statistically significant relationship between organizational perspective and organizational commitment.

H1g0: There is no statistically significant relationship between relationship with subordinate and organizational commitment.

H1h0: There is no statistically significant relationship between personal feedback and organizational commitment. 


\section{Type of Research}

To achieve the objectives of the study, hypotheses are developed and tested via using comparative and quantitative research design. In quantitative research, sampling is typically representative and randomized, to ensure that results can be generalized from a sample to a population and also that participants with certain characteristics are adequately represented in the sample. In contrast, sampling in qualitative studies is typically purposeful, with the goal of intentionally sampling cases that can best help the investigator understand the central problem under study (Jane Forman et al., 2008). Yet, due to the fact that population in this study is small, the whole population will be used to test the hypothesis above.

\subsection{Questionnaire Design}

A Questionnaire was used to test the hypotheses, so a quantitative research design was implemented since such type of research's measurement provides the fundamental connection between empirical observation and mathematical expression of quantitative relationships, where Yahoo-Maktoob is the company under study. This part of the questionnaire contains five questions. Each question addresses one of the respondent's demographic characteristic such as gender, age, academic degree, experience years, and the management level.

\subsection{Population and Sampling}

Saunders et al. (2011) explained that the choice of sampling techniques and sample size depended on the feasibility of collecting data which will lead to answering the main research questions, as well as addressing it is objectives as a matter that it is also influenced by the availability of resources. They explained: "All your choices will be dependent on your ability to gain access to organizations" (p. 235). Because this study is conducted to examine the relationship between communication satisfaction and organizational commitment in Yahoo! Maktoob, the population consists of all the employees of Yahoo! Maktoob office in Amman/ Jordan, which are: 107 employees (2012). Based on that, total of (107) employee have accepted to cooperate with this study. Such number representes the successful questionnaires that are suitable for the analysis.

\subsection{Validity, Reliability and Piloting}

Reliability is the degree to which an instrument produces the same results with repeated administration (Beanland et al., 1999; Polit \& Hungler, 1999; Considine et al., 2005). A high level of reliability is important when the effect of an intervention on knowledge is measured using a pre-test/post-test design. Concepts related to reliability are consistency, precision, stability, equivalence and internal consistency (Beanland et al., 1999). Regarding how to measure reliability; it can be measured using correlation coefficients or reliability coefficients (Beanland et al., 1999; Polit \& Hungler, 1999; Considine et al., 2005). The data used for reliability and validity analysis in this study are typically obtained during a pilot study. Such ample, as a materr of fact, is a representative of the eventual target population in terms of range and level of ability. Moreover, it is employed to ensure the most effective and understandable wording method and to determine whether the data collection procedures are effective and successful. The initial draft of questionnaire has been prepared and initial data have been gathered from a group of 25 employees (a sample of all the employees) who work in different departments and in different managerial levels. In addition, notes and feedback about the clarity of the questions and how employees understood each question they were provided with, and the questions that were not clear enough to the employees were re-written.

\section{Data Collection and Analysis}

The questionnaire was intended to be self-completed. In a sense that this approach entailed in-person delivery of hand copies of the questionnaires to respondents and follow up until collecting the responses. The first part of the questionnaire is concerned with five employees' demographic characteristics which are: gender, age, academic degree, experience years, and management level. Results explores that about $62 \%$ of study respondents are males and the rest are females. Regarding the sample's age and educational distribution, results indicate that the majority of study sample ages $(91.6 \%)$ are less than 35 years old and $(81.3 \%)$ are holding Bachelor degrees. Regarding the respondents' experience longevity, results show that $62.6 \%$ of respondents have less than 5 years experience and $26.6 \%$ of them have from 5 to less than 10 years experience. With-in the same line, about $84 \%$ of study respondents are employees and the rest are managers.

\section{Inferential Statistics: Hypotheses Testing Results}

Simple regression and multiple regression, alongside with other statistical tests are utilized to accomplish the hypotheses testing objective. Results of hypotheses testing are further discussed and analyzed to come up with conclusions and results of the research. 


\subsection{The First Main Hypothesis-H10}

H10: There is no statistically significant relationship between communication satisfaction and organizational commitment.

A crucial step in hypothesis testing is to determine the significance level $(\alpha)$; the maximum allowable type I error. Often 0.05 is used, and it is considered to be acceptable for this research. Thus the decision rule is to reject the null hypothesis if the $\rho$-value $<=0.05$. As listed in the table below, the $\rho$-value $0.000<0.05$. Thus, the implied decision is to reject H10.

Table 1. Communication satisfaction regressed against organizational commitment—model summary

\begin{tabular}{lllll}
\hline Model & $\mathrm{R}$ & R Square & Adjusted R Square & Std. Error of the Estimate \\
\hline 1 & $.759^{\mathrm{a}}$ & .576 & .572 & .737 \\
\hline \multicolumn{4}{l}{ a. Predictors: (Constant), Communication-Satisfaction } \\
\hline
\end{tabular}

Table 2. Communication satisfaction regressed against organizational commitment—Anova

\begin{tabular}{lllllll}
\hline Model & & Sum of Squares & df & Mean Square & F & Sig. \\
\hline 1 & Regression & 77.527 & 1 & 77.527 & 142.859 & $.000^{\mathrm{a}}$ \\
& Residual & 56.982 & 105 & .543 & & \\
& Total & 134.508 & 106 & & & \\
\hline
\end{tabular}

Table 3. Communication satisfaction regressed against organizational commitment - coefficients

\begin{tabular}{lllllll}
\hline & & \multicolumn{2}{l}{ Unstandardized Coefficients } & \multicolumn{2}{l}{ Standardized Coefficients } & \\
Model & & $\mathrm{B}$ & Std. Error & Beta & $\mathrm{t}$ & Sig. \\
\hline 1 & & 1.055 & .315 & & 3.350 & .001 \\
& (Constant) & & & .759 & 11.952 & .000 \\
\hline
\end{tabular}

The correlation coefficient $\mathrm{R}=0.759$ indicates that there is a positive correlation between communication satisfaction and organizational commitment. This means that the independent variable and dependent variable change in the same direction. The correlation coefficient is a gauge of how well the model predicts the observed data. In terms of the variability of organizational commitment accounted for the model, $\mathrm{R}$ square represents this variability. The value of $R$ square 0.576 , indicates the amount of variations in the organizational commitment variable that is accounted by the fitted model. It plots that $57.6 \%$ of the variability of organizational commitment has been explained by communication satisfaction. The adjusted $\mathrm{R}$ square tells us about the generalizability of the model. It allows us to generalize the results taken from the respondents to the whole population. In this case it equals 0.572 . It is noticed that the adjusted $\mathrm{R}$ square has almost the same value as $\mathrm{R}$ square. If the adjusted $\mathrm{R}$ square is excluded from $\mathrm{R}$ square $(0.576-0.572=0.004)$, a value of $0.004 \mathrm{can}$ be found which shrinkage means that if the model has been fitted when the whole population participates rather than those responded in the study. The next step is the analysis of variance (ANOVA) that allows to statistically test the null hypothesis. Looking at the ANOVA analysis, it can be concluded that F- ratio for these data is 142.859 which is significant at $\rho<0.05$ (Alpha in this case equals sig $=0.000$ ). The result shows that there is less than a $0.05 \%$ chance that an $\mathrm{F}$ - ratio of this value would happen by chance alone. Therefore, it can be concluded that there is statistically significant relationship between communications satisfaction and organizational commitment and thus reject the null hypothesis and accept the alternative hypothesis. Finally, communications satisfaction has a statistically significant relationship with organizational commitment, where hypothesis 1 has been tested.

\subsection{The First Sub Hypothesis-H1aO}

Since the hypotheses H2 to H9 imply exploring linear relationships between the predictor (independent) variable that is represented by eight dimensions and the criterion (dependent) variable that is represented by three dimensions. Multiple Regression is the statistical technique used to test it.

H1a0: There is no statistically significant relationship between communication climate and organizational commitment. 
Table 4. Communication climate regressed against organizational commitment-model summary

\begin{tabular}{lllll}
\hline Model & $\mathrm{R}$ & R Square & Adjusted R Square & Std. Error of the Estimate \\
\hline 1 & $.727^{\mathrm{a}}$ & .529 & .496 & .800 \\
\hline
\end{tabular}

Table 5. Communication climate regressed against organizational commitment—Avova

\begin{tabular}{lllllll}
\hline Model & & Sum of Squares & $\mathrm{df}$ & Mean Square & $\mathrm{F}$ & Sig. \\
\hline 1 & Regression & 71.177 & 7 & 10.168 & 15.895 & $.000^{\mathrm{a}}$ \\
& Residual & 63.331 & 99 & .640 & & \\
& Total & 134.508 & 106 & & & \\
\hline
\end{tabular}

Table 6. Communication climate regressed against organizational commitment—coefficients

\begin{tabular}{|c|c|c|c|c|c|c|c|c|}
\hline & & \multicolumn{2}{|c|}{ Unstandardized Coefficients } & \multicolumn{3}{|l|}{ Standardized Coefficients } & \multicolumn{2}{|c|}{ Collinearity Statistics } \\
\hline \multicolumn{2}{|c|}{ Model } & $\mathrm{B}$ & Std. Error & Beta & $\mathrm{t}$ & Sig. & Tolerance & VIF \\
\hline \multirow[t]{8}{*}{1} & (Constant) & 1.116 & .392 & & 2.847 & .005 & & \\
\hline & Communication Climate1 & .082 & .062 & .119 & 1.316 & .191 & .579 & 1.728 \\
\hline & Communication Climate2 & .163 & .079 & .212 & 2.054 & .043 & .448 & 2.230 \\
\hline & Communication Climate3 & .058 & .070 & .080 & .825 & .411 & .509 & 1.966 \\
\hline & Communication Climate4 & .114 & .080 & .150 & 1.427 & .157 & .428 & 2.335 \\
\hline & Communication Climate5 & -.013 & .044 & -.021 & -.285 & .776 & .890 & 1.123 \\
\hline & Communication Climate6 & .257 & .073 & .327 & 3.547 & .001 & .560 & 1.786 \\
\hline & Communication Climate7 & .056 & .063 & .078 & .884 & .379 & .612 & 1.635 \\
\hline
\end{tabular}

The adjusted $\mathrm{R}$ square value indicates that the model has accounted for $49.6 \%$ of the variance in the criterion variable; organizational commitment. The standardized Beta Coefficient reported in the table above give a measure of the contribution of each variable to the model. Beta values indicate that these are all significant variables in the model. In addition, it has been noted that Communication Climate item (number 5) "Extent to which communication practices in Yahoo-Maktoob which are adaptable to emergencies" has the largest impact on organizational commitment. Regarding the VIF value, it should not be higher than 10.0 , which is the case in the data in hand.

\subsection{The Second Sub Hypothesis-H1b0}

H1b0: There is no statistically significant relationship between the relationship to superiors and organizational commitment.

Table 7. The relationship to superiors regressed against organizational commitment—model summary

\begin{tabular}{lllll}
\hline Model & R & R Square & Adjusted R Square & Std. Error of the Estimate \\
\hline 1 & $.591^{\mathrm{a}}$ & .349 & .324 & .926 \\
\hline
\end{tabular}

Table 8. The relationship to superiors regressed against organizational commitment—ANOVA

\begin{tabular}{lllllll}
\hline Model & & Sum of Squares & $\mathrm{df}$ & Mean Square & $\mathrm{F}$ & Sig. \\
\hline 1 & Regression & 46.971 & 4 & 11.743 & 13.683 & $.000^{\mathrm{a}}$ \\
& Residual & 87.537 & 102 & .858 & & \\
& Total & 134.508 & 106 & & & \\
\hline
\end{tabular}


Table 9. The relationship to superiors regressed against organizational commitment-coefficients

\begin{tabular}{|c|c|c|c|c|c|c|c|c|}
\hline \multirow{2}{*}{\multicolumn{2}{|c|}{ Model }} & \multicolumn{2}{|c|}{ Unstandardized Coefficients } & \multicolumn{3}{|l|}{ Standardized Coefficients } & \multicolumn{2}{|c|}{ Collinearity Statistics } \\
\hline & & $\mathrm{B}$ & Std. Error & Beta & $\mathrm{t}$ & Sig. & Tolerance & VIF \\
\hline \multirow[t]{5}{*}{1} & (Constant) & 2.833 & .289 & & 9.812 & .000 & & \\
\hline & Relationship To Superiors1 & .121 & .083 & .186 & 1.457 & .148 & .393 & 2.545 \\
\hline & Relationship To Superiors2 & -.078 & .098 & -.120 & -.792 & .430 & .277 & 3.616 \\
\hline & Relationship To Superiors3 & .175 & .082 & .295 & 2.120 & .036 & .329 & 3.042 \\
\hline & Relationship To Superiors4 & .183 & .077 & .293 & 2.396 & .018 & .426 & 2.347 \\
\hline
\end{tabular}

\subsection{The Third Sub Hypothesis-H1c0}

$\mathrm{H} 1 \mathrm{c} 0$ : There is no statistically significant relationship between organizational integration and organizational commitment.

Table 10. Organizational integration regressed against organizational commitment—model summary

\begin{tabular}{lllll}
\hline Model & $\mathrm{R}$ & R Square & Adjusted R Square & Std. Error of the Estimate \\
\hline 1 & $.711^{\mathrm{a}}$ & .505 & .480 & .812 \\
\hline
\end{tabular}

Table 11. Organizational integration regressed against organizational commitment-ANOVA

\begin{tabular}{lllllll}
\hline Model & & Sum of Squares & df & Mean Square & F & Sig. \\
\hline 1 & Regression & 67.917 & 5 & 13.583 & 20.602 & $.000^{\mathrm{a}}$ \\
& Residual & 66.591 & 101 & .659 & & \\
& Total & 134.508 & 106 & & & \\
\hline
\end{tabular}

Table 12. Organizational integration regressed against organizational commitment—coefficients

\begin{tabular}{|c|c|c|c|c|c|c|c|c|}
\hline & & \multicolumn{2}{|c|}{$\begin{array}{l}\text { Unstandardized } \\
\text { Coefficients }\end{array}$} & \multicolumn{3}{|l|}{$\begin{array}{l}\text { Standardized } \\
\text { Coefficients }\end{array}$} & \multicolumn{2}{|c|}{ Collinearity Statistics } \\
\hline \multicolumn{2}{|c|}{ Model } & $\mathrm{B}$ & Std. Error & Beta & $\mathrm{t}$ & Sig. & Tolerance & VIF \\
\hline \multirow[t]{6}{*}{1} & (Constant) & 2.050 & .300 & & 6.826 & .000 & & \\
\hline & Organizational Integration1 & .094 & .073 & .131 & 1.302 & .196 & .484 & 2.066 \\
\hline & Organizational Integration2 & -.049 & .068 & -.069 & -.721 & .472 & .534 & 1.874 \\
\hline & Organizational Integration3 & .156 & .074 & .211 & 2.105 & .038 & .486 & 2.056 \\
\hline & Organizational Integration4 & .258 & .074 & .376 & 3.499 & .001 & .423 & 2.362 \\
\hline & Organizational Integration5 & .111 & .064 & .172 & 1.748 & .084 & .504 & 1.982 \\
\hline
\end{tabular}

The adjusted $\mathrm{R}$ square value indicates that the model has accounted for $48 \%$ of the variance in the criterion variable; organizational commitment. The standardized Beta Coefficient reported in the table above give a measure of the contribution of each variable to the model. Beta values indicate that these are significant variables in the model. And that item 4 (Information about the requirements of my job) has the largest impact on the organizational commitment. Regarding the VIF value, it should not be higher than 10.0, which is the case in the data available.

\subsection{The Fourth Sub Hypothesis-H1d0}

$\mathrm{H} 1 \mathrm{~d} 0$ : There is no statistically significant relationship between media quality and organizational commitment.

Table 13. Media quality regressed against organizational commitment-model summary

\begin{tabular}{lllll}
\hline Model & $\mathrm{R}$ & R Square & Adjusted R Square & Std. Error of the Estimate \\
\hline 1 & $.668^{\mathrm{a}}$ & .446 & .429 & .851 \\
\hline
\end{tabular}


Table 14. Media quality regressed against organizational commitment-ANOVA

\begin{tabular}{lllllll}
\hline Model & & Sum of Squares & df & Mean Square & F & Sig. \\
\hline 1 & Regression & 59.939 & 3 & 19.980 & 27.597 & $.000^{\text {a }}$ \\
& Residual & 74.569 & 103 & .724 & & \\
& Total & 134.508 & 106 & & & \\
\hline
\end{tabular}

Table 15. Media quality regressed against organizational commitment—coefficients

\begin{tabular}{|c|c|c|c|c|c|c|c|c|}
\hline & & \multicolumn{2}{|c|}{ Unstandardized Coefficients } & \multicolumn{3}{|l|}{ Standardized Coefficients } & \multicolumn{2}{|c|}{ Collinearity Statistics } \\
\hline \multicolumn{2}{|c|}{ Model } & $\mathrm{B}$ & Std. Error & Beta & $\mathrm{T}$ & Sig. & Tolerance & VIF \\
\hline \multirow[t]{4}{*}{1} & (Constant) & 2.141 & .296 & & 7.244 & .000 & & \\
\hline & Media Quality1 & .280 & .082 & .392 & 3.430 & .001 & .411 & 2.432 \\
\hline & Media Quality2 & .097 & .088 & .134 & 1.097 & .275 & .360 & 2.776 \\
\hline & Media Quality3 & .153 & .063 & .231 & 2.417 & .017 & .589 & 1.699 \\
\hline
\end{tabular}

The adjusted $\mathrm{R}$ square value indicates that the model has accounted for $42.9 \%$ of the variance in the criterion variable; organizational commitment. The standardized Beta Coefficient reported in the table above give a measure of the contribution of each variable to the model. Beta values indicate that these are all significant variables in the model and it can be noted that Media Quality item number 1 of "Extent to which the organization's communications are interesting and helpful" has the largest impact on organizational commitment. Regarding the VIF value, it should not be higher than 10.0, which is the case in the data in hand.

\subsection{The FifthSub Hypothesis-H1e0}

$\mathrm{H} 1 \mathrm{e} 0$ : There is no statistically significant relationship between horizontal and informal communication and organizational commitment.

Table 16. Horizontal and informal communication regressed against organizational commitment—model summary

\begin{tabular}{lllll}
\hline Model & $\mathrm{R}$ & R Square & Adjusted R Square & Std. Error of the Estimate \\
\hline 1 & $.592^{\mathrm{a}}$ & .350 & .332 & .921 \\
\hline
\end{tabular}

Table 17. Horizontal and informal communication regressed against organizational commitment-ANOVA

\begin{tabular}{lllllll}
\hline Model & & Sum of Squares & df & Mean Square & F & Sig. \\
\hline 1 & Regression & 47.138 & 3 & 15.713 & 18.524 & $.000^{\mathrm{a}}$ \\
& Residual & 87.370 & 103 & .848 & & \\
& Total & 134.508 & 106 & & & \\
\hline
\end{tabular}

Table 18. Horizontal and informal communication regressed against organizational commitment—coefficients

\begin{tabular}{|c|c|c|c|c|c|c|c|}
\hline \multirow[b]{2}{*}{ Model } & \multicolumn{2}{|c|}{ Unstandardized Coefficients } & \multicolumn{3}{|l|}{ Standardized Coefficients } & \multicolumn{2}{|c|}{ Collinearity Statistics } \\
\hline & $\mathrm{B}$ & Std. Error & Beta & $\mathrm{t}$ & Sig. & Tolerance & VIF \\
\hline 1 (Constant) & 2.234 & .376 & & 5.937 & .000 & & \\
\hline $\begin{array}{l}\text { Horizontal And Informal } \\
\text { Communication1 }\end{array}$ & .101 & .084 & .128 & 1.210 & .229 & .560 & 1.785 \\
\hline $\begin{array}{l}\text { Horizontal And Informal } \\
\text { Communication } 2\end{array}$ & .102 & .075 & .125 & 1.351 & .180 & .739 & 1.353 \\
\hline $\begin{array}{l}\text { Horizontal And Informal } \\
\text { Communication } 3\end{array}$ & .311 & .069 & .442 & 4.495 & .000 & .651 & 1.535 \\
\hline
\end{tabular}

The adjusted $\mathrm{R}$ square value indicates that the model has accounted for $33.2 \%$ of the variance in the criterion variable; organizational commitment. The standardized Beta Coefficient reported in the table above give a 
measure of the contribution of each variable to the model. Beta values indicate that these are all significant variables in the model and horizontal and informal item number 3 of "Extent to which my subordinates feel responsible for initiating accurate upward communication" has the largest impact on organizational commitment. Regarding the VIF value, it should not be higher than 10.0, which is the case in the data in hand.

\subsection{The Sixth Sub Hypothesis-HIfO}

H1f0: There is no statistically significant relationship between organizational perspective and organizational commitment.

Table 19. Organizational perspective regressed against organizational commitment—model summary

\begin{tabular}{lllll}
\hline Model & R & R Square & Adjusted R Square & Std. Error of the Estimate \\
\hline 1 & $.731^{\mathrm{a}}$ & .535 & .507 & .791 \\
\hline
\end{tabular}

Table 20. Organizational perspective regressed against organizational commitment-ANOVA

\begin{tabular}{lllllll}
\hline Model & & Sum of Squares & df & Mean Square & F & Sig. \\
\hline 1 & Regression & 71.925 & 6 & 11.988 & 19.155 & $.000^{\mathrm{a}}$ \\
& Residual & 62.583 & 100 & .626 & & \\
& Total & 134.508 & 106 & & & \\
\hline
\end{tabular}

Table 21. Organizational perspective regressed against organizational commitment—coefficients

\begin{tabular}{llllllll}
\hline & \multicolumn{2}{c}{ Unstandardized Coefficients } & Standardized Coefficients & $\mathrm{t}$ & \multicolumn{2}{c}{ Sig. } & \multicolumn{2}{c}{ Collinearity Statistics } \\
Model & $\mathrm{B}$ & Std. Error & Beta & & & Tolerance & VIF \\
\hline 1 (Constant) & 1.840 & .286 & & 6.437 & .000 & & \\
Organizational Perspective1 & .262 & .080 & .377 & 3.271 & .001 & .350 & 2.858 \\
Organizational Perspective2 & -.088 & .069 & -.150 & -1.283 & .202 & .343 & 2.919 \\
Organizational Perspective3 & .077 & .092 & .114 & .832 & .408 & .247 & 4.046 \\
Organizational Perspective4 & .058 & .083 & .091 & .702 & .485 & .277 & 3.609 \\
Organizational Perspective5 & .056 & .070 & .085 & .805 & .423 & .416 & 2.405 \\
Organizational Perspective6 & .217 & .064 & .310 & 3.392 & .001 & .558 & 1.792 \\
\hline
\end{tabular}

The adjusted $\mathrm{R}$ square value indicates that the model has accounted for $50.7 \%$ of the variance in the criterion variable; organizational commitment. The standardized Beta Coefficient reported in the table above give a measure of the contribution of each variable to the model. Beta values indicate that these are significant variables in the model and organizational perspective item number 1 of "Information about organizational policies and goals" has the largest impact on organizational commitment. Regarding the VIF value, it should not be higher than 10.0, which is the case in the data in hand.

\subsection{The Seventh Sub Hypothesis - HIgO}

$\mathrm{H1g0:}$ There is no statistically significant relationship between relationship with subordinate and organizational commitment.

Table 22. The relationship with subordinate regressed against organizational commitment-model summary

\begin{tabular}{lllll}
\hline Model & R & R Square & Adjusted R Square & Std. Error of the Estimate \\
\hline 1 & $.694^{\mathrm{a}}$ & .481 & .461 & .827 \\
\hline
\end{tabular}


Table 23. Relationship with subordinate regressed against organizational commitment—Anova

\begin{tabular}{lllllll}
\hline Model & & Sum of Squares & df & Mean Square & F & Sig. \\
\hline 1 & Regression & 64.714 & 4 & 16.178 & 23.644 & $.000^{\text {a }}$ \\
& Residual & 69.794 & 102 & .684 & & \\
& Total & 134.508 & 106 & & & \\
\hline
\end{tabular}

Table 24. Relationship with subordinate regressed against organizational commitment — coefficients

\begin{tabular}{|c|c|c|c|c|c|c|c|c|}
\hline & & \multicolumn{2}{|c|}{ Unstandardized Coefficients } & \multicolumn{3}{|c|}{ Standardized Coefficients } & \multicolumn{2}{|c|}{ Collinearity Statistics } \\
\hline \multicolumn{2}{|c|}{ Model } & $\mathrm{B}$ & Std. Error & Beta & $\mathrm{t}$ & Sig. & Tolerance & VIF \\
\hline 1 & (Constant) & 2.034 & .291 & & 6.982 & .000 & & \\
\hline & Relationship With Subordinates1 & .125 & .080 & .178 & 1.578 & .118 & .401 & 2.491 \\
\hline & Relationship With Subordinates2 & .352 & .094 & .465 & 3.733 & .000 & .328 & 3.048 \\
\hline & Relationship With Subordinates3 & .059 & .082 & .083 & .715 & .476 & .382 & 2.615 \\
\hline & Relationship With Subordinates4 & .019 & .061 & .030 & .303 & .763 & .521 & 1.919 \\
\hline
\end{tabular}

The adjusted $\mathrm{R}$ square value indicates that the model has accounted for $46.1 \%$ of the variance in the criterion variable; organizational commitment. The standardized Beta Coefficient reported in the table above give a measure of the contribution of each variable to the model. Beta values indicate that these are all significant variables in the modeland therelationship with subordinates item number 2 of "Extent to which my subordinates are responsive to downward directive communication." has the largest impact on organizational commitment. Regarding the VIF value, it should not be higher than 10.0, which is the case in the data in hand.

\subsection{The Eighth Sub Hypothesis-H1h0}

H1h0: There is no statistically significant relationship between personal feedback and organizational commitment.

Table 25. The personal feedback regressed against organizational commitment—model summary

\begin{tabular}{lllll}
\hline Model & R & R Square & Adjusted R Square & Std. Error of the Estimate \\
\hline 1 & $.611^{\mathrm{a}}$ & .373 & .348 & .909 \\
\hline
\end{tabular}

Table 26. The personal feedback regressed against organizational commitment—Anova

\begin{tabular}{lllllll}
\hline Model & & Sum of Squares & df & Mean Square & F & Sig. \\
\hline 1 & Regression & 50.183 & 4 & 12.546 & 15.175 & $.000^{\mathrm{a}}$ \\
& Residual & 84.325 & 102 & .827 & & \\
& Total & 134.508 & 106 & & & \\
\hline
\end{tabular}

Table 27. The personal feedback regressed against organizational commitment — coefficients

\begin{tabular}{|c|c|c|c|c|c|c|c|c|}
\hline & & \multicolumn{2}{|c|}{ Unstandardized Coefficients } & \multicolumn{3}{|l|}{ Standardized Coefficients } & \multicolumn{2}{|c|}{ Collinearity Statistics } \\
\hline \multicolumn{2}{|c|}{ Model } & $\mathrm{B}$ & Std. Error & Beta & $\mathrm{t}$ & Sig. & Tolerance & VIF \\
\hline \multirow[t]{5}{*}{1} & (Constant) & 2.454 & .315 & & 7.780 & .000 & & \\
\hline & The Personal Feedback1 & .169 & .094 & .246 & 1.797 & .075 & .328 & 3.047 \\
\hline & The Personal Feedback2 & .108 & .092 & .146 & 1.168 & .246 & .391 & 2.560 \\
\hline & The Personal Feedback3 & .007 & .085 & .010 & .079 & .937 & .407 & 2.459 \\
\hline & The Personal Feedback4 & .196 & .082 & .282 & 2.394 & .019 & .442 & 2.262 \\
\hline
\end{tabular}

The adjusted $\mathrm{R}$ square value indicates that the model has accounted for $34.8 \%$ of the variance in the criterion variable; organizational commitment. The standardized Beta Coefficient reported in the table above give a measure of the contribution of each variable to the model. Beta values indicate that these are all significant 
variables in the model. In addition, it has been found that the personal feedback item number 4 of "Reports on how problems in my job are being handled." has the largest impact on organizational commitment. Regarding the VIF value, it should not be higher than 10.0, which is the case in the data in hand.

\section{Discussion and Summary}

The nature of different communicational channels and methods by which the top management can reach its employees within the organization is one of the most essential aspects of managing the organizing and delivery of high quality products and services. The success of communication satisfaction is mainly determined through the communicational methods, processes, and techniques, making them vital for organizational commitment among employees.

The literature review showed that communication satisfaction has been related positively to organizational commitment. Allen (1992), for example, found that, especially in organizations involved in total quality management, communication variables explained up to 59 percent of the variance in organizational commitment. Ridder (2004) found that having organizational commitment is the function of task-related information that should be clearly determined, while McDonald \& Gandz (1991) denoted that commitment was important for the human relations inside and outside any organization. As the hypothesized model of this research indicates; that communication satisfaction has a significant direct impact on organizational commitment. Furthermore, Argenti (1998) and Soupata (2005) studies' results showed that organization related information can be distributed to employees through a variety of channels such as supervisors, group meetings, brochures and newsletters, company websites, and mission statements. So these methods can affect organizational commitment, because employees feel as though they have a sense of ownership, and knowing more about the internal procedures, will increase the employees' attachments to their employers because they will see themselves as core members, and contribute to the organization's goals. Also, it has been shown that communication satisfaction and organizational commitment is a "psychological stabilizing or obliging force that binds individuals to courses of action relevant" to the organization (Bentein et al., 2005), and that is what has been found from the statistical results from the analyses conducted.

The first main hypothesis is tested via using Simple Regression statistical technique; the testing shows that there is a statistically significant relationship between communication satisfaction (The independent variable) and organizational commitment (The dependent variable). The correlation coefficient $\mathrm{R}=0.759$ which is the value taken from the first table indicated that there is a positive correlation between communication satisfaction and organizational commitment. This means that independent variables and dependent variable are changeable within in the same direction. So the null hypothesis was rejected because the significant value resulted from the AVOVA table was 0.000 which is $<$ the $\rho$ value $(0.05)$. Regarding the sub hypothesis H1a0 (There is no statistically significant relationship between communication climate and organizational commitment), it was rejected since it was tested using a multiple regression statistical technique, and the correlation coefficient of $\mathrm{R}=$ 0.0727 indicated that there is a positive relationship between communication climate and organizational commitment. In addition, Beta values indicated that all the values are significant variables in the model. So the second null hypothesis was also rejected as the significant value $<0.05$. The sub hypothesis H1b0 (There is no statistically significant relationship between the relationship to superiors and organizational commitment). This hypothesis was tested and the value of correlation coefficient $\mathrm{R}=0.591$, and the beta values, and the significant value $\rho$ indicated that the null hypothesis should be rejected and that there is a significant relationship between the relationship to superiors and organizational commitment.

In the sub hypothesis $\mathrm{H} 1 \mathrm{c} 0$ (There is no statistically significant relationship between organizational integration and organizational commitment), the statistical technique of multiple regression indicates that standardized Beta Coefficient reported give a measure of the contribution of each variable to the model. Beta values indicated that these are significant variables in the model, so this null hypothesis was rejected since the correlation coefficient $\mathrm{R}=0.711$ indicated that there is a relationship between organizational integration and organizational commitment Within the same line, testing the sub hypothesis $\mathrm{H} 1 \mathrm{~d} 0$ (There is no statistically significant relationship between media quality and organizational commitment) indicated that the Beta values showed that these are all significant variables in the model, as well as the $\mathrm{R}=0.668$ indicated that the null hypothesis was rejected and that there is a relationship between media quality and organizational commitment.

Regarding the sub hypothesis H1e0 (There is no statistically significant relationship between horizontal and informal communication and organizational commitment), the multiple regression technique showed that the Beta values indicated that these are all significant variables in the model, as well as the $\mathrm{R}=0.592$, indicated that the null hypothesis was rejected and the alternative hypothesis was taken in its the place and that there is a real 
relationship between the said variables. To add more, in the process of testing sub hypothesis $\mathrm{H} 1 \mathrm{fO}$ (There is no statistically significant relationship between organizational perspective and organizational commitment), the multiple regression indicated that the standardized Beta Coefficient reported gave a measure of the contribution of each variable to the model. Beta values indicated that those were significant variables in the model, and the $\mathrm{R}=0.731$ showed that the alternative hypothesis took place and the null hypothesis was rejected, as a result there is a relationship between organizational perspective and organizational commitment. Regarding the sub hypothesis H1g0 (There is no statistically significant relationship between relationship with subordinate and organizational commitment) the value of $\mathrm{R}=0.694$ indicated that there is a relationship between the said variables as the $\rho$ value (which was 0.00 ) is less than 0.05 . In the hypothesis is $\mathrm{H} 1 \mathrm{~h} 0$ (There is no statistically significant relationship between personal feedback and organizational commitment) Multiple Regression statistical technique was used to test this hypothesis and the $\rho$ value (significant value) was 0.000 which is $<\alpha$ value which is $(0.05)$. Beta values indicated that those were all significant variables in the model and indicated that there is a statistically significant relationship between personal feedback and organizational commitment.

\section{Study Contributions-Future Research Insights and Study Limitation}

This study adds new knowledge to internet organizations, the adoption of new technology and techniques to deliver high levels of communication satisfaction among subordinates and superiors, and how it affects organizational commitment. Furthermore, it proposed a new measure of communication satisfaction applied in the internet companies in Jordan, and examined the impact of communication satisfaction on organizational commitment. The main contribution of this study comes from the fact that this study is one of the few to be carried out with the aim of addressing communication satisfaction in the internet industry in Jordan. Moreover, the literature does not record efforts for measuring communication satisfaction with organizational commitment while this study reveals a positive relationship between communication satisfaction and organizational commitment. It would be interesting to explore the relationship between communication satisfaction and a new intervening variable and then study its impact on the organizational commitment. A number of limitations were associated with the quantitative part of this study. First, the results in this study were based on a single organization with a small population of 107 employees, so caution must be exercised in generalizing to other organizations. Second, the use of only one data collection method, the questionnaire, brings to light the lack of support for findings results from data analyses. In addition, although random sampling method was used, the seriousness of respondents was somewhat questionable. Such access-related, sampling-related, and cultural issues add more to the limitations and difficulties confronted this research. Furthermore, although the knowledge transforming function was hypothesized in this study, no data were available that can directly test the importance of this matter. That enhance the fact that these data should also be collected in the future. It is important to mention that managers will not be able to encourage effective organizational commitment through communication practices unless they recognize and understand what information is valued by subordinates.

\section{References}

Akroyd, D., Legg, J., Jackowski, M. B., \& Adams, R. D. (2009). The impact of selected organizational variables and managerial leadership on radiation therapists' organizational commitment. Radiography, 15(2), 113-120. http://dx.doi.org/10.1016/j.radi.2008.05.004

Al Kahtani, A., \& Sulayman, A. (2013). Leader Charisma, Employee Organizational Commitment, and Organizational Change: A Proposed Theoretical Framework. International Journal of Academic Research in Business and Social Sciences, 3(5), 377-399.

Al-Duhaish, A., Alshurideh, M., Masa'deh, R. E., \& Al-Zu'bi, Z. B. M. (2014). The Impact of the Basic Reference Group Usage on the Purchasing Decision of Clothes (A Field Study of Saudi Youth in Riyadh City). Dirasat: Administrative Sciences, 41(2), 201-221.

Al-dweeri, R. M., Obeidat, Z. M., Al-dwiry, M. A., Alshurideh, M. T., \& Alhorani, A. M. (2017). The Impact of E-Service Quality and E-Loyalty on Online Shopping: Moderating Effect of E-Satisfaction and E-Trust. International Journal of Marketing Studies, 9(2), 92-103. http:/doi.org/10.5539/ijms.v9n2p92

Alkalha, Z., Al-Zu'bi, Z., Al-Dmour, H., Alshurideh, M., \& Masa'deh, R. (2012). Investigating the effects of human resource policies on organizational performance: An empirical study on commercial banks operating in Jordan. European Journal of Economics, Finance and Administrative Sciences, 51, 44-64.

Allen, M. W. (1992). Communication and organizational commitment: Perceived organizational support as a mediating factor. Communication Quarterly, 40(4), 357-367. http://dx.doi.org/10.1080/01463379209369852

Allen, N. J., \& Meyer, J. P. (1997). Commitment in the workplace: Theory, research and application. Thousand 
Oaks: Sage.

Almajali, D. A., Masa'deh, R., \& Tarhini, A. (2016). Antecedents of ERP Systems Implementation Success: A Study on Jordanian Healthcare Sector. Journal of Enterprise Information Management, 29(4), 549-565. http://dx.doi.org/10.1108/JEIM-03-2015-0024

Al-Meer, A. A. (1989). Organizational commitment: a comparison of westerners, Asians and Saudis. International Studies of Management and Organizations, $19(2), \quad 74-84$. http://dx.doi.org/10.1080/00208825.1989.11656505

Alshurideh, M. (2010). Customer Service Retention-A Behavioural Perspective of the UK Mobile Market. PhD dissertation. Durham University.

Alshurideh, M. (2014). The Factors Predicting Students' Satisfaction with Universities' Healthcare Clinics' Services: A Case-Study from the Jordanian Higher Education Sector. Dirasat: Administrative Sciences, 41(2), 451-464. https://doi.org/10.12816/0007482

Alshurideh, M. (2016). Is Customer Retention Beneficial for Customers: A Conceptual Background. Journal of Research in Marketing, 5(3), 382-389. http://dx.doi.org/10.17722/jorm.v5i3.126

Alshurideh, M. T. (2014). A Qualitative Analysis of Customer Repeat Purchase Behaviour in the UK Mobile Phone Market. Journal of Management Research, 6(1), 109-125. http://dx.doi.org/10.5296/jmr.v6i1.4659

Alshurideh, M. T. (2016). Exploring the Main Factors Affecting Consumer Choice of Mobile Phone Service Provider Contracts. Int. J. Communications, Network and System Sciences, 9, 563-581. http://dx.doi.org/10.4236/ijens.2016.912044

Alshurideh, M., \& Al-dmour, H. (2008). The Influence of Promotional Mix Elements on Jordanian Consumer's Decision Cell Phone Services Usage: An Analytical Study Jordan. Journal of Business Administration, 4(4), 375-392.

Alshurideh, M., (2016). Scope of Customer Retention Problem in the Mobile Phone Sector: A Theoretical Perspective. Journal of Marketing and Consumer Research, 20, 64-69.

Alshurideh, M., Alhadeed, A. Y., \& Barween, A. (2015). The effect of internal marketing on organizational citizenship behavior an applicable study on the University of Jordan employees. International Journal of Marketing Studies, 7(1), 138-145. http://dx.doi.org/10.5539/ijms.v7n1p138

Alshurideh, M., Al Kurdi, B. H., Vij, A., Obiedat, Z., \& Naser, A. (2016). Marketing Ethics and Relationship Marketing: An Empirical Study that Measure the Effect of Ethics Practices Application on Maintaining Relationships with Customers. International Business Research, 9(9), 8-90. http://dx.doi.org/10.5539/ibr.v9n9p78

Alshurideh, M., Bataineh, A., Alkurdi, B., \& Alasmr, N. (2015). Factors affect Mobile Phone Brand Choices-Studying the Case of Jordan Universities Students. International Business Research, 8(3), 141-155. http://dx.doi.org/10.5539/ibr.v8n3p141

Alshurideh, M., Masa'deh, R., \& Alkurdi, B. (2012). The Effect of Customer Satisfaction upon Customer Retention in the Jordanian Mobile Market: An Empirical Investigation. European Journal of Economics, Finance and Administrative Sciences, 47, 69-78.

Alshurideh, M., Nicholson, M., \& Xiao, S. (2012). The Effect of Previous Experience on Mobile Subscribers' Repeat Purchase Behaviour. European Journal of Social Sciences, 30(3), 366-376.

Alshurideh, M. T., Shaltoni, A. M., \& Hijawi, D. A. S. (2014). Marketing Communications Role in Shaping Consumer Awareness of Cause-Related Marketing Campaigns. International Journal of Marketing Studies, 6(2), 163-168. http://dx.doi.org/10.5539/ijms.v6n2p163

Altamony, H., Alshurideh, M., \& Obeidat, B. (2012). Information Systems for Competitive Advantage: Implementation of an Organisational Strategic Management Process. Proceedings of the 18th IBIMA Conference on Innovation and Sustainable Economic Competitive Advantage: From Regional Development to World Economic, Istanbul, Turkey, 9th-10th May.

Angel, H. L., \& Perry, S. L. (1981). An Empirical Assessment of Organizational Communication and Organizational Effectiveness. Administrative Science Quarterly, 26, 1-14. https://doi.org/10.2307/2392596

Applbaum, R. L. (1973). Fundamental concepts in human communication. San Francisco: Canfield Press.

Argenti, P. A. (1998). Strategic employee communications. Human Resource Management (1986-1998), 37(3-4), 
199-206. https://doi.org/10.1002/(SICI)1099-050X(199823/24)37:3/4<199::AID-HRM3>3.0.CO;2-R

Beanland, C., Schneider, Z., LoBiondo-Wood, G., \& Haber, J. (1999). Nursing research methods. Critical Appraisal and Utilisation.

Bem, D. J. (1967). Self-perception: An alternative interpretation of cognitive dissonance. Psychological Review, 74, 183-200. http://dx.doi.org/10.1037/h0024835

Bentein, K., Vandenberg, R., Vandenberghe, C., \& Stinglhamber, L. (2005). The role of change in the relationship between commitment and turnover: a latent growth modeling approach. Journal of Applied Psychology, 90(3), 468-482. http://dx.doi.org/10.1037/0021-9010.90.3.468

Broom, G. M., \& Dozier, D. M. (1983). An overview: Evaluation research in public relations. Public Relations Quarterly, 28(3), 5-8.

Cappelli, P. (2000). Managing without commitment. Organizational Dynamics, 28(4), 11-24. http://dx.doi.org/10.1016/S0090-2616(00)00008-5

Chen, J., Silverthorne, C., \& Hung, J. (2006). Organisation communication, job stress, organisational commitment, and job performance of accounting professionals in Taiwan and America. Leadership \& Organisation Development Journal, 27(4), 242-249. http://dx.doi.org/10.1108/01437730610666000

Cohen, A. (1991). Career stage as a moderator of the relationships between organizational commitment and its outcomes: A meta-analysis. Journal of Occupational Psychology, 64, 253-268. https://doi.org/10.1111/j.2044-8325.1991.tb00558.x

Considine, J., Botti, M., \& Thomas, S. (2005). Design, format, validity and reliability of multiple choice questions for use in nursing research and education. Collegian, 12(1), 19-24. http://dx.doi.org/10.1016/S1322-7696(08)60478-3

Cooper-Hakim, A., \& Viswesvaran, C. (2005). The construct of work commitment: testing an integrative framework. Psychological Bulletin, 131(2), 241-259. http://dx.doi.org/10.1037/0033-2909.131.2.241

D'Amato, A., \& Herzfeldt, R. (2008). Learning orientation, organizational commitment and talent retention across generations. Journal of Managerial Psychology, 23(8), 929-953. http://dx.doi.org/10.1108/02683940810904402

De Meyer, A., Nakane, J., Miller, J. M., \& Ferdows, K. (1989). Flexibility: the next competitive battle: the manufacturing futures survey. Strategic Management Journal, 10(2), 135-144. https://doi.org/10.1002/smj.4250100204

Downs, C. W., \& Hazen, M. D. (1977). A factor analytic study of communication satisfaction. The Journal of Business Communication, 14, 64-73. https://doi.org/10.1177/002194367701400306

Downs, C. W., Downs, A., Potvin, T., Varona, E., Gribas, J. S., \& Ticehurst, W. (1995). A cross-cultural comparison of relationships between organizational commitment and organizational communication. In International Communication Association Convention (pp. 1-22). Albuquerque, NM.

ELSamen, A. A., \& Alshurideh, M. (2012). The impact of internal marketing on internal service quality: A Case study in a Jordanian pharmaceutical company. International Journal of Business and Management, 7(19), 84-95. https://doi.org/10.5539/ijbm.v7n19p84

Forman, J., Creswell, J. W., Damschroder, L., Kowalski, C. P., \& Krein, S. L. (2008). Qualitative research methods: Key features and insights gained from use in infection prevention research. American Journal of Infection Control, 36(10), 764-771. http://dx.doi.org/10.1016/j.ajic.2008.03.010

Garnett, J. (1992). Communicating for Results in Government: A Strategic Approach for Public Managers. SanFranciso, CA: Jossey-Bass Publishers.

Garnett, J., \& Kouzmin, A. (1979). Handbook of Administrative Communication. New York: Marcel Dekker, Inc.

Ghannajeh, A. M., AlShurideh, M., Zu'bi, M. F., Abuhamad, A., Rumman, G. A., Suifan, T., \& Akhorshaideh, A. H. O. (2015). A qualitative analysis of product innovation in Jordan's pharmaceutical sector. European Scientific Journal, 11(4), 474-503.

Goldhaber, G. M. (1993). Organizational communication. Madison: Brown \& Benchmark.

Goldhaber, G., Porter, D., Yates, M., \& Lesniak, R. (1978). Organisational communication: 1978. Human Communication Research, 5(1), 76-96. https://doi.org/10.1111/j.1468-2958.1978.tb00624.x 
Goris, J., Vaught, B., \& Pettit, J. (2000). Effects of communication direction on job performance and satisfaction: a moderated regression analysis. The Journal of Business Communication, 37(4), 348-368. https://doi.org/10.1177/002194360003700402

Gould-Williams, J. (2003). The importance of HR practices and workplace trust in achieving superior performance: a study of public-sector organizations. International Journal of Human Resource Management, 14(1), 28-54. http://dx.doi.org/10.1080/09585190210158501

Hausknecht, J. P., Rodda, J., \& Howard, M. J. (2009). Targeted employee retention: Performance-based and job-related differences in reported reasons for staying. Human Resource Management, 48, 269-288. https://doi.org/10.1002/hrm.20279

Holland, C. P., Light, B., \& Gibson, N. (1999). A critical success factors model for enterprise resource planning implementation. In Proceedings of the 7th European Conference on Information Systems, 1, 273-287.

Hom, P. W., Tsui, A. S., Wu, J. B., Lee, T. W., Zhang, A. Y., Fu, P. P., \& Li, L. (2009). Explaining employment relationships with social exchange and job embeddedness. Journal of Applied Psychology, 94(2), 277-297. http://dx.doi.org/10.1037/a0013453

Jablin, L. L. Putnam, K. H., \& Porter, L. W. (Eds.) (1987). Handbook of organizational communication: An interdisciplinary perspective (pp. 70-96). Newbury Park, CA: Sage.

Johnson, M. D., \& Fornell, C. (1991). A framework for comparing customer satisfaction across individuals and $\begin{array}{lllll}\text { product } & \text { categories. Journal Economic Psychology, 12(2), 267-286. }\end{array}$ http://dx.doi.org/10.1016/0167-4870(91)90016-M

Keyton, J. (2011).Communication and Organizational Culture: A key to understanding Work Experience (2nd ed.). Newbury Park, CA: Sage Publication, Inc., USA.

Kim, T. Y., Cable, D. M., \& Kim, S. P. (2005). Socialization tactics, employee proactivity, and person-organization fit. Journal of Applied Psychology, 90(2), 232-241. http://dx.doi.org/10.1037/0021-9010.90.2.232

Kwantes, C. T. (2007). Organizational commitment, intellectual capital and organizational competitiveness, South Asia Journal of Management, 14(3), 28-43.

Larson, E., \& Fukami, C. (1984). Relationships between worker behavior and commitment to the organization and union. Proceedings of the Academy of Management, 1, 222-226. https://doi.org/10.5465/AMBPP.1984.4979013

Laschinger, H. K. S. (2004). Hospital nurses' perceptions of respect and organizational justice. Journal of Nursing Administration, 34(7-8), 354-364. https://doi.org/10.1097/00005110-200407000-00009

Lee, R. (2009). Social capital and business and management: Setting a research agenda. International Journal of Management Reviews, 11(3), 247-273. https://doi.org/10.1111/j.1468-2370.2008.00244.x

Madlock, P. E., \& Kennedy-Lightsey, C. (2010). The effects of supervisors' verbal aggressiveness and mentoring on their subordinates. Journal of Business Communication, 47(1), 42-62. https://doi.org/10.1177/0021943609353511

Malmelin, N. (2007). Communication capital: Modelling corporate communications as an organisational asset. Corporate Communications: An International Journal, 12(3), 298-310. http://dx.doi.org/10.1108/13563280710776888

Masa'deh, R. (2012). The Impact of Management Information Systems (MIS) on Quality Assurance (QA): A Case Study in Jordan. International Journal of Information, Business and Management, 4(2), 93-110.

Masa'deh, R., Obeidat, B., \& Tarhini, A. (2016). A Jordanian Empirical Study of the Associations among Transformational Leadership, Transactional Leadership, Knowledge Sharing, Job Performance, and Firm Performance: A Structural Equation Modelling Approach. Journal of Management Development, 35(5), 681-705. http://dx.doi.org/10.1108/JMD-09-2015-0134

Masa'deh, R., Tayeh, M., \& Al-Jarrah, I. M. (2015). Accounting vs. Market-based Measures of Firm Performance Related to Information Technology Investments. International Review of Social Sciences and Humanities, 9(1), 129-145.

Mathieu, J., \& Zajac, D. M. (1990). A review and metaanalysis of the antecedents, correlates, and consequences of organizational commitment. Psychological Bulletin, 108, 171-194. 
http://dx.doi.org/10.1037/0033-2909.108.2.171

Mattila, A. S., \& Enz, C. A. (2002). The role of emotions in service encounters. Journal of Service Research, 4, 268-277. https://doi.org/10.1177/1094670502004004004

McCarthy, Sh., Jaafar, J., Kamal, A., \& Zubair, A. (2013). Psychology at work in Asia. Proceeds of the 3ed and 4th Asian Psychological Association Conference and the 4th international Conference on Organizational Psychology. Newcastle, UK: Cambridge Scholars Publishing.

Mcdonald, P., \& Gandz, J. (1991). Identification of values relevant to business research. Human Resource Management, 30(2), 217-236. https://doi.org/10.1002/hrm.3930300205

Meng, J., \& Pan, P. L. (2012). Using a balanced set of measures to focus on long-term competency in internal communication. Public Relations Review, 38, 484-490. http://dx.doi.org/10.1016/j.pubrev.2012.03.005

Meyer, J. P., \& Allen, N. J. (1991). A three-component conceptualization of organizational commitment. Human Resource Management Review, 1(1), 61-89. http://dx.doi.org/10.1016/1053-4822(91)90011-Z

Meyer, J. P., Stanley, D. J., Herscovitch, L., \& Topolnytsky, L. (2002). Affective, continuance, and normative commitment to the organization: A meta-analysis of antecedents, correlates, and consequences. Journal of Vocational Behavior, 61, 20-52. http://dx.doi.org/10.1006/jvbe.2001.1842

Michael, J., Tarn, H., \& Wen, J. (2002). Exploring organizational expansion modes and their associated communication system requirements: consolidation and complementation. International Journal of Information Management, 22(1), 3-26. http://dx.doi.org/10.1016/S0268-4012(01)00039-1

Mitchell, T. R., Holtom, B. C., \& Lee, T. W. (2001). How to keep your best employees: Developing an effective retention policy. The Academy of Management Executive, 15(4), 96-108. https://doi.org/10.5465/AME.2001.5897929

Moorman, C., Deshpande, R., \& Zaltman, G. (1993). Factors affecting trust in market research relationships. The Journal of Marketing, 57(1), 81-101. https://doi.org/10.2307/1252059

Morris, J. H., \& Sherman, J. D. (1981). Generalizability of an organizational commitment model. Academy of Management Journal, 24(3), 512-526. https://doi.org/10.2307/255572

Morrow, P. C. (2011). Managing organizational commitment: Insights from longitudinal research. Journal of Vocational Behavior, 14, 18-35. http://dx.doi.org/10.1016/j.jvb.2010.12.008

Mowday, R. T., Porter, L. M., \& Steers, R. M. (1982). Employee-Organization Linkages: The Psychology of Commitment, Absenteeism and Turnover. New York, NY: Academic Press.

Mowday, R. T., Porter, L. W., \& Dubin, R. (1974). Unit performance, situational factors, and employee attitudes in spatially separated work units. Organizational Behavior and Human Performance, 12, 231-248. http://dx.doi.org/10.1016/0030-5073(74)90048-8

Obeidat, B., Al-Suradi, M., \& Tarhini, A. (2016). The Impact of Knowledge Management on Innovation: An Empirical Study on Jordanian Consultancy Firms. Management Research Review, 39(10), 1214-1238. http://dx.doi.org/10.1108/MRR-09-2015-0214

Obeidat, B., Sweis, R., Zyod, D., \& Alshurideh, M. (2012). The effect of perceived service quality on customer loyalty in internet service providers in Jordan. Journal of Management Research, 4(4), $224-242$. https://doi.org/10.5296/jmr.v4i4.2130

Pandey, S., \& Garnett, J. (2006). Exploring public sector communication performance: testing a model and drawing implications. Public Administration Review, 66, 37-51. https://doi.org/10.1111/j.1540-6210.2006.00554.x

Pettit, J., Goris, J., \& Vaught, B. (1997). An examination of organisational communication as a moderator of the relationship between job performance and job satisfaction. Journal of Business Communication, 34(1), 81-98. https://doi.org/10.1177/002194369703400105

Pincus, J. D. (1986). Communication satisfaction, job satisfaction, and job performance. Human Communication Research, 12(3), 395-419. https://doi.org/10.1111/j.1468-2958.1986.tb00084.x

Polit, D. F., \& Hungler, B. P. (1999). Nursing Research: Principles and Methods (6th ed.). Philadelphia, Lippincott.

Porter, L. W., Crampon, W. J., \& Smith, F. W. (1976). Organizational commitment and managerial turnover: A longitudinal study. Organizational Behavior and Human Performance, 15, 87-98. 
http://dx.doi.org/10.1016/0030-5073(76)90030-1

Postmes, T., Tanis, M., \& De Wit, B. (2001). Communication and commitment in organizations: A social identity approach. Group Processes \& Intergroup Relations, 4(3), 227-246. https://doi.org/10.1177/1368430201004003004

Putti, J. M., Aryee, S., \& Phua, J. (1990). Communication relationship satisfaction and organizational $\begin{array}{llll}\text { commitment. Group \& Organization } \quad \text { Management, } & \text { 15(1), }\end{array}$ https://doi.org/10.1177/105960119001500104

Randall, D. M. (1990). The consequences of organizational commitment: Methodological investigation. Journal of Organizational Behavior, 11, 361-378. https://doi.org/10.1002/job.4030110504

Rathi, N., \& Rastogi, R. (2009). Assessing the relationship between emotional intelligence, occupational self-efficacy and organizational commitment. Journal of the Indian Academy of Applied Psychology, 35, 93-102.

Ridder, J. A. (2004). Organisational communication and supportive employees. Human Resource Management Journal, 14(3), 20-30. https://doi.org/10.1111/j.1748-8583.2004.tb00124.x

Riketta, M. (2002). Attitudinal organizational commitment and job performance: A meta-analysis. Journal of Organizational Behavior, 23, 257-266. https://doi.org/10.1002/job.141

Riketta, M., \& Van Dick, R. (2005). Foci of attachment in organizations: A meta-analytic comparison of the strength and correlates of workgroup versus organizational identification and commitment. Journal of Vocational Behavior, 67, 490-510. http://dx.doi.org/10.1016/j.jvb.2004.06.001

Ritter, M. (2003). The use of balanced scorecards in the strategic management of corporate communication. $\begin{array}{lllll}\text { Corporate } \quad \text { Communications: An International Journal, } & 8(1), \quad 44-59 .\end{array}$ http://dx.doi.org/10.1108/13563280310458911

Robson, P. J. A., \& Tourish, D. (2005). Managing internal communication: an organizational case study. Corporate Communications: An International Journal, 10(3), 213-22. http://dx.doi.org/10.1108/13563280510614474

Rodwell, J. J., Kienzle, R., \& Shadur, M. A. (1998). The relationships among work-related perceptions, employee attitudes, and employee performance: the integral role of communication. Human Resource Management, $37(3 / 4)$, 277-293. https://doi.org/10.1002/(SICI)1099-050X(199823/24)37:3/4<277::AID-HRM9>3.0.CO;2-E

Rousseau, D. M. (1998). Why workers still identify with organizations. Journal of Organizational Behavior, 19(3), 217-233. https://doi.org/10.1002/(SICI)1099-1379(199805)19:3<217::AID-JOB931>3.0.CO;2-N

Salancik, G. R., \& Pfeffer, J. (1978). A social information processing approach to job attitudes and task design. Administrative Science Quarterly, 23, 224-235. https://doi.org/10.2307/2392563

Saunders, M. N., Saunders, M., Lewis, P., \& Thornhill, A. (2011). Research methods for business students (5th ed.). Delhi, India: Pearson Education India.

Scott-Ladd, B., Travaglione, A., \& Marshall, V. (2006). Causal inferences between participation in decision making, task attributes, work effort, rewards, job satisfaction and commitment. Leadership \& Organization Development Journal, 27(5), 399-414. http://dx.doi.org/10.1108/01437730610677990

Shannak, R., Masa'deh, R., Al-Zu'bi, Z., Obeidat, B., Alshurideh, M., \& Altamony, H. (2012). A theoretical perspective on the relationship between knowledge management systems, customer knowledge management, and firm competitive advantage. European Journal of Social Sciences, 32(4), 520-532.

Shannak, R., Masa'deh, R., Obeidat, B., \& Almajali, D. (2010). Information Technology Investments: A Literature Review. Proceedings of the 14th IBIMA Conference on Global Business Transformation through Innovation and Knowledge Management: An Academic Perspective, Istanbul-Turkey, 23rd-24th June, pp. 1356-1368.

Soupata, L. (2005). Engaging employees in company success: The UPS approach to a winning team. Human Resource Management, 44(1), 95-98. https://doi.org/10.1002/hrm.20046

Steers, R. M. (1977). Antecedents and outcomes of organizational commitment. Administrative Science Quarterly, 22(1), 46-56. https://doi.org/10.2307/2391745

Stuart, H. (1999). Towards a definite model of the corporate identity management process. Corporate 
Communication, 4(4), 200-207. http://dx.doi.org/10.1108/13563289910299328

Sundaram, D. S., \& Webster, C. (2000). The role of nonverbal communication in service encounters. Journal of Services Marketing, 14, 378-391. http://dx.doi.org/10.1108/08876040010341008

Thompkins, P. K. (1987). Translating organizational theory: Symbolism over substance. In F. M. Jablin, L. L. Putnam, K. H. Roberts, \& L. W. Porter (Eds.), Handbook of organizational communication: An interdisciplinary perspective (pp. 70-96). Newbury Park, CA: Sage.

Tourish, D., \& Hargie, O. (2009). Communication and organisational success. In O. Hargie, \& D. Tourish (Eds.), Auditing organisational success. London: Routledge.

Van Dick, R., \& Riketta, M. (2006). Bindung von Mitarbeitern an Organisationen [Employees'commitment to organizations]. Zeitschrift fur Personalpsychologie, 5, 83-84. https://doi.org/10.1026/1617-6391.5.3.83

Vandenberg, R. J., Richardson, H. A., \& Eastman, L. J. (1999). The impact of high involvement work processes on organizational effectiveness a second-order latent variable approach. Group \& Organization Management, 24(3), 300-339. https://doi.org/10.1177/1059601199243004

Vedabrata, B., Hartono, E., Lederer, A. L., \& Vijay, S. (2002). The impact of organizational commitment, senior management involvement, and team involvement on strategic information systems planning. Information\& Management, 39(6), 513-524. http://dx.doi.org/10.1016/S0378-7206(01)00115-X

Vratskikh, I., Al-Lozi, M., \& Maqableh, M. (2016). The Impact of Emotional Intelligence on Job Performance via the Mediating Role of Job Satisfaction. International Journal of Business and Management, 11, 69-91. https://doi.org/10.5539/ijbm.v11n2p69

Watson, T. (2010). Capitalizing on Effective Communication. Communication ROI Study Report.

Yammarino, F. J., \& Naughton, T. J. (1988). Time spent communicating: A multiple levels of analysis approach. Human Relations, 41(9), 655-676. https://doi.org/10.1177/001872678804100902

Zu’bi, M. F., Al-Lozi, M., Dahiyat, S. E., Alshurideh, M., \& Al Majali, A. (2012). Examining the effects of quality management practices on product variety. European Journal of Economics, Finance and Administrative Sciences, 51, 10-19.

\section{Copyrights}

Copyright for this article is retained by the author, with first publication rights granted to the journal.

This is an open-access article distributed under the terms and conditions of the Creative Commons Attribution license (http://creativecommons.org/licenses/by/4.0/). 